\title{
DNA EXTRACTION FROM FORMALIN FIXED FRANCISCANA TISSUES
}

\author{
Diego Rodríguez ${ }^{1}$, Ricardo Bastida $^{1}$ and Per-Erik Olsson ${ }^{2}$
}

\begin{abstract}
The present paper reports the extraction of DNA from formalin-fixed Pontoporia blainvillei tissues. Following the Vachot and Monerot (1996) protocol, fragmented DNA (300-700bp) was extracted from more than 95\% of liver and muscle samples. DNA yield in liver samples was significantly higher than in muscle samples $(4.574 \pm 1.169 \mu \mathrm{g}$ DNA/mg versus $0.808 \pm$ $0.297 \mu \mathrm{g}$ DNA/mg). Similar results were obtained from nine other species of cetaceans and five species of pinnipeds. It is of special interest to have a method that allows the utilisation of museum specimens not originally preserved for genetic studies, which may include rarely available, declining or extinct species.

Resúmen - El presente trabajo reporta la extracción de ADN a partir de tejidos formolizados de Pontoporia blainvillei. Siguiendo el protocolo de Vachot y Monerot (1996) se pudo extraer ADN degradado (300-700pb) en más del 95\% de las muestras de hígado y músculo analizadas. El rendimiento en ADN fue significativamente mayor en muestras de hígado que en muestras de músculo (4.574 $\pm 1.169 \mu \mathrm{g}$ DNA/mg tejido húmedo versus $0.808 \pm 0.297 \mu \mathrm{g} \mathrm{DNA} / \mathrm{mg}$ tejido húmedo). Resultados similares se obtuvieron en otras nueve especies de Cetáceos y cinco de Pinnípedos. Resulta de gran interés contar con un método que permita la utilización de especímenes depositados en museos y que no hayan sido originalmente colectados para estudios genéticos, incluyendo especies de difícil obtención, en franca declinación o extintas.
\end{abstract}

Keywords: Franciscana, DNA extraction, microsatellites, formalin, liver, muscle.

\section{Introduction}

The utilisation of genetic markers in the study of phylogeny, behavioural ecology and population biology has increased dramatically during the last decades. For the application of these techniques it is essential to obtain tissue samples that allow the proper extraction of nucleic acids. In order to avoid genetic degradation, samples from sacrificed specimens or from biopsy material should be immediately frozen or fixed. Cryopreservation and saline DMSO solution at room temperature are the usual options for soft tissue preservation (Dessauer and Hafner, 1984; Amos and Hoelzel, 1991; Sherwin, 1991; Dierauf, 1994; Bilton and Jaarola, 1996).

Marine mammals cannot be sacrificed and therefore samples can only be obtained from dead or incidentally killed animals, increasing the risk of post-mortem decomposition. This is of particular importance in the case of the franciscana (Pontoporia blainvillei), because most specimens are obtained from incidental catches or strandings. Biopsy or sloughed skin sampling from live animals, currently applied to a number of species, would be extremely difficult (or almost impossible) to obtain from franciscanas.

Formalin is the most acceptable fluid for soft tissue preservation, and is by far the most widely used in collections, particularly for Pontoporia. The possibility to extract DNA from formalin-fixed samples not originally preserved for genetic analysis, would open great possibilities to analyse a great variety of marine mammal species for which tissues are stored in museums or international tissue banks. This could increase not only the possibility to study rare or extinct species, but also to study populations both on a wide time scale and wide distribution around the world.
The present study reports the results of extraction of genetic material from formalin fixed tissues of P. blainvillei, and other marine mammal species.

\section{Material and Methods}

A total of 39 samples from 24 franciscanas collected in northern waters of Argentina were analysed. The samples were derived from two different treatments; the first group was fixed in formalin $(10 \% \mathrm{v} / \mathrm{v})$ for approximately 3 months before analysis, whereas a second group of liver samples were immediately fixed in formalin during the necropsies (storage time 40-50 months) (Table 1). All the samples, still stored in formalin, were transported to the Department of Molecular Biology (Umeå University) for further DNA analysis.

The tissues were pulverised in liquid nitrogen under aseptic conditions and treated with the phenol-chloroform procedures of DNA extraction of Sambrook et al. (1993; n=5) and Vachot and Monerot (1996; n=34; Appendix I). Freshly sampled liver from rainbow trout (Oncorhynchus mykiss) was used as a positive control for the extraction procedures. Following extraction, 8 to $12 \mu 1$ samples were run on agarose electrophoresis gels (1.0-1.5\%) containing ethidium bromide and were photographed under UV light to estimate the size range of DNA fragments. The same procedures were performed in a set of samples from nine other cetacean species (Delphinus delphis, Tursiops truncatus, Stenella coeruleoalba, Orcinus orca, Phocoena spinipinnis, Ziphius cavirostris, Kogia breviceps, Physeter catodon and Eubalaena australis) and five pinniped species (Arctocephalus australis, A. tropicalis, A. gazella, Otaria flavescens and Mirounga leonina).

To quantify the DNA extracted, a subset of 70-140mg samples of liver $(n=8)$ and muscle $(n=4)$ were analysed by

\footnotetext{
${ }^{1}$ Consejo Nacional de Investigaciones Científicas y Técnicas (CONICET) and Departamento de Ciencias Marinas, Facultad de Ciencias Exactas y Naturales, Universidad Nacional de Mar del Plata. Casilla de Correo 43, (7600) Mar del Plata, Argentina.

- Corresponding author: dhrodri@mdp.edu.ar.

${ }^{2}$ Department of Molecular Biology, Division of Physiology, Umeå University. SE-901 87, Umeå, Sweden.
} 
UV-VIS spectrophotometer at $280 \mathrm{~nm}$ wavelength with $1 \mathrm{~mm}$ cells. The concentration and purity of the samples were determined using the 260/280nm absorbance ratio (Sambrook et al., 1993), and only samples with absorbance ratios between 1.8 and 2.0 were used. For comparison, DNA was also quantified from formalin fixed tissues of common dolphins $(n=4)$, South American fur seals $(n=6)$ and Subantarctic fur seals $(n=5)$.

Table 1. Franciscana samples analysed in the present study. See Materials and Methods for sample treatment description.

\begin{tabular}{cccc}
\hline Tissue & $\begin{array}{c}40-50 \text { months } \\
\text { in Formalin }\end{array}$ & $\begin{array}{c}\text { 3 months } \\
\text { in Formalin }\end{array}$ & Total \\
\hline \hline Muscle & --- & 7 & 7 \\
Liver & 4 & 28 & 32 \\
Total & 4 & 35 & 39 \\
\hline \hline
\end{tabular}

\section{Results}

No DNA material could be detected in agarose gel electrophoresis of the samples extracted with the protocol of Sambrook et al. (1993); increasing times in proteinase K digestion (up to $72 \mathrm{hrs}$ ) produced no results. In contrast, DNA was obtained in $96.7 \%$ of the samples treated with the protocol of Vachot and Monerot (1996; Table 2). The amount of DNA extracted (Table 3 ) ranged from 0.25 to $7.26 \mu \mathrm{g}$ DNA/ $\mathrm{mg}$ tissue $(\mathrm{w} / \mathrm{w})$, and the mean yield of DNA from liver samples was significantly higher than from muscle samples (Mann-Whitney $\mathrm{U}<0.001 ; \mathrm{p}=0.021$ ). A comparison of liver samples belonging to the same specimens resulted in a significantly higher DNA yield in samples fixed for 3 months than in those fixed for 40-50 months (MannWhitney $\mathrm{U}<0.001 ; \mathrm{p}=0.020)$. A gross estimation of annual degradation rate reached about $23 \%$ (Table 4 ).
Table 2. Extraction efficiency, defined as the percentage of the samples that resulted in a positive DNA extraction, recorded for both extraction protocols. Number of samples appears in brackets.

\begin{tabular}{ccc}
\hline \hline Tissue & Sambrook et.al & Vachot-Monerot \\
\hline \hline Muscle & $0 \%[2]$ & $80.0 \%[5]$ \\
Liver & $0 \%[3]$ & $100 \%[29]$ \\
Total & $0 \%[5]$ & $96.7 \%[34]$ \\
\hline \hline
\end{tabular}

A comparison of the yields obtained for franciscanas, common dolphins and fur seals revealed no differences between seal and dolphin species for either muscle (ANOVA; $F(3,7)=3.300 ; p=0.09)$ or liver $(\operatorname{ANOVA} ; \mathrm{F}(3,8)=2.375$; $\mathrm{p}=0.146)$ samples.

The extracted material was degraded, with fragments ranging from 300 to $700 \mathrm{bp}$, but in some cases high molecular weight DNA was successfully extracted (e.g. Figure 1 lanes 9 and 12). The same protocol applied to formalin fixed liver and muscle samples of other marine mammals produced similar results (Figure 2).

\section{Discussion}

Around the world innumerable specimens are preserved in museums, and many of them are almost impossible to re-sample for genetic analyses. Many authors emphasize the importance of museums as sources of DNA for retrospective studies (Houde and Braun, 1988; Paabo et al., 1989; Paabo, 1993), and there is an increasing utilisation of preserved specimens for genetic studies, including histological paraffin embedded tissues (e.g. Greer et al.,1989; Stanta and Schneider, 1991; Tyrrell et al., 1995). Other studies focus on dry or mummified tissues and special extraction protocols have been developed for such tissues (e.g. Paabo,

Table 3. DNA yield in muscle and liver samples of selected marine mammals, expressed as $\mu \mathrm{g} D N A / m g$ of tissue (wet weight). Fixation time $=3$ months.

\begin{tabular}{lccc}
\hline \multirow{2}{*}{ Species } & \multicolumn{3}{c}{ DNA yield [mean \pm SD $(\mathrm{n}=)]$} \\
& Muscle & Liver & Overall \\
\hline \hline Pontoporia blainvillei & $0.808 \pm 0.297(4)$ & $4.574 \pm 1.169(4)$ & $2.691 \pm 2.162(8)$ \\
Arctocephalus australis & $1.446 \pm 0.616(3)$ & $4.541 \pm 1.793(3)$ & $2.994 \pm 2.069(6)$ \\
Arctocephalus tropicalis & $0.527 \pm 0.385(2)$ & $3.693 \pm 1.248(3)$ & $2.427 \pm 1.955(5)$ \\
Delphinus delphis & $0.415 \pm 0.023(2)$ & $6.854 \pm 0.599(2)$ & $3.635 \pm 3.733(4)$ \\
\hline \hline Overall & $0.860 \pm 0.532(11)$ & $4.723 \pm 1.550(12)$ & $2.877 \pm 2.287(23)$ \\
\hline \hline
\end{tabular}

Table 4. DNA yield in liver samples obtained from the same specimens and exposed to different preservation times, expressed as $\mu \mathrm{g}$ DNA/mg of tissue (wet weight). Annual Degradation Rate was calculated as the percentage of DNA lost during the prolonged formalin exposure, presented on a 12-month basis.

\begin{tabular}{lccc}
\hline \multicolumn{1}{c}{ Type of Franciscana } & \multicolumn{2}{c}{ DNA yield [Months of Formalin Fixation] } & $\begin{array}{c}\text { Annual } \\
\text { Degradation } \\
\text { Rate }\end{array}$ \\
\hline \hline Adult Female & Brief Exposure & Long Exposure & $23.5 \%$ \\
Juvenile Female & $5.24[3 \mathrm{mo}]$ & $1.14[40 \mathrm{mo}]$ & $24.2 \%$ \\
Juvenile Female & $3.70[3 \mathrm{mo}]$ & $0.19[47 \mathrm{mo}]$ & $23.3 \%$ \\
Adult Male & $5.87[3 \mathrm{mo}]$ & $0.18[50 \mathrm{mo}]$ & $23.8 \%$ \\
\hline Mean \pm SD & $3.48[3 \mathrm{mo}]$ & $0.03[50 \mathrm{mo}]$ & $23.7 \pm 0.39 \%$ \\
\hline \hline
\end{tabular}


1989; Hagelberg et al., 1991; Hagelberg and Clegg, 1991; Cano and Poinar, 1993). Liquid-preserved specimens have been much less studied until recently (Criscuolo, 1992; Goebel and Simmons 1993; Vachot and Monerot, 1996). The present study confirms that it is possible to extract DNA from formalin fixed marine mammal tissues.

Sample preservation in either dry ice or liquid nitrogen has proven to be the most efficient method for DNA preservation (Dessauer and Hafner, 1984; Sherwin, 1991; Dierauf, 1994; Bilton and Jaarola, 1996), although its utilisation is sometimes very difficult under field conditions. Liquid fixatives can be used at room temperature during necropsies, and DMSO saline solutions result in little or no DNA degradation (Amos and Hoelzel, 1991). Nevertheless samples originally stored for decades in museum standard collections or tissue banks are rarely preserved in fixatives other than formalin or alcohol.

The Vachot and Monerot (1996) protocol was found to be highly efficient, as extraction was successful in more than $95 \%$ of the samples studied, including liver and muscle samples belonging to fifteen marine mammal species. The yield was low if compared with that from fresh tissues (about $8 \mu \mathrm{g}$ DNA/mg fresh tissue; Bilton and Jaarola, 1996), but the maximum values of DNA concentration found $(7 \mu \mathrm{g} /$ $\mathrm{mg}$ in liver and $2 \mu \mathrm{g} / \mathrm{mg}$ in muscle) were even higher than those obtained in DMSO fixed bird tissues (0.7-3.25 $\mu \mathrm{g}$ DNA/ mg tissue) by Seutin et al. (1991). The consistent pattern obtained when comparing liver samples from the same franciscanas at different exposure times (Table 4) confirms the results of Vachot and Monerot (1996), who found that DNA degradation increases and yield decreases with time. The significantly higher yield found in liver was also found in avian tissues (Seutin et al., 1991) and these values make the liver a target organ to be sampled for DNA studies, whereas values obtained from muscle tissue are encouraging since it is the tissue most commonly found in formalin-fixed specimens.

The observed DNA degradation is in agreement with previous reports on dry marine mammal bones and baleen (Dizon et al., 1995; Kimura et al., 1997), and it is a common feature of ancient DNA (Paabo, 1993). Not withstanding, recent studies have been successfully performed using highly degraded material (e.g. Kohn and Wayne, 1997).

The low-yield extraction of degraded DNA was a challenge prior to the development of PCR-based analysis of microsatellites. These markers, with arrays usually less than a few hundred nucleotides in length (Rassman et al., 1991) proved to be extremely versatile and promising (Brufford and Wayne, 1993; Queller et al., 1993; Wright and Bentzen, 1994; Goldstein and Schlotterer, 1999). They are extensively used in marine mammal studies aimed at determining population social structure and mating systems (Amos et al., 1993; Clapham and Palsboll, 1997). They are also used for genetic

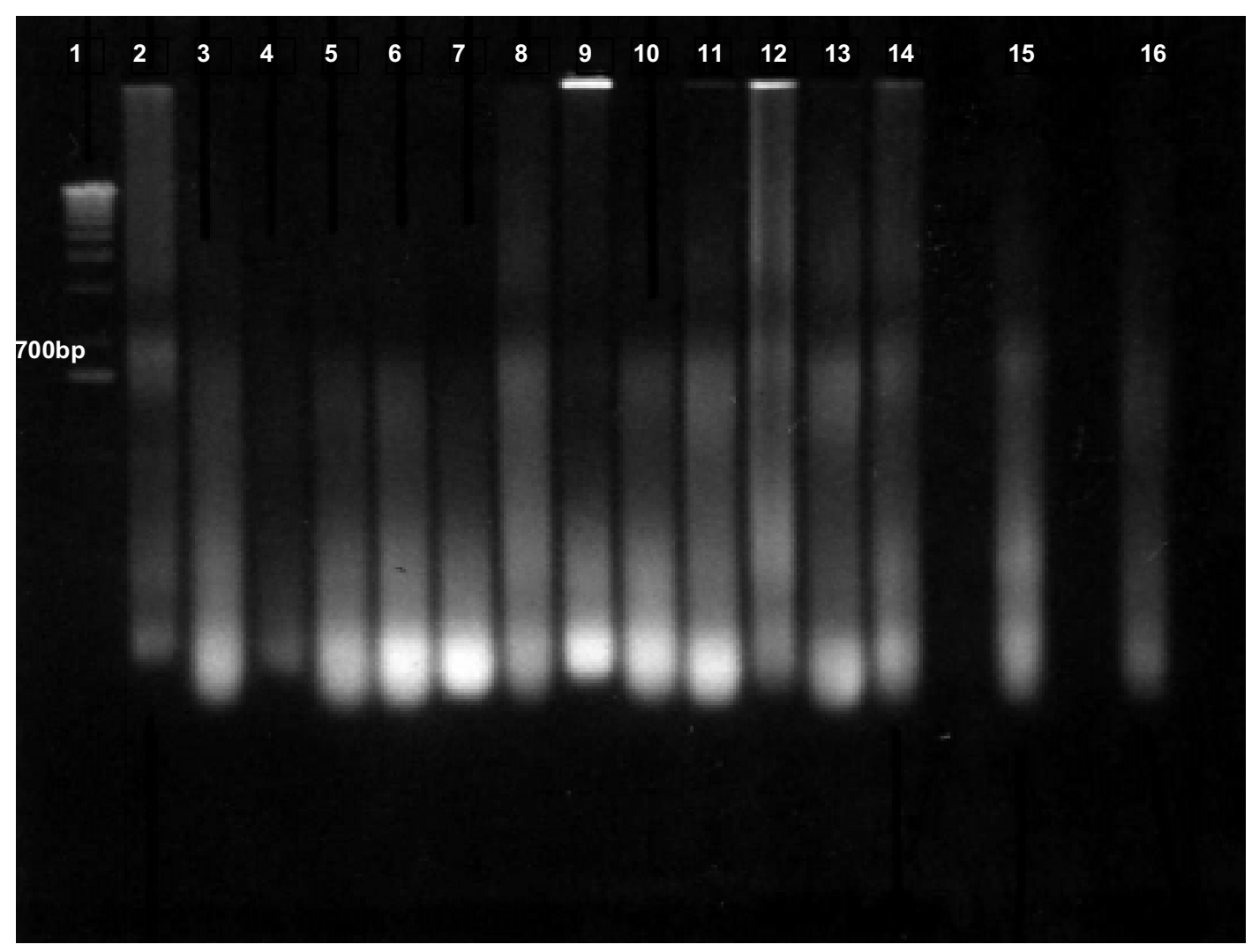

Figure 1. Separation of muscle and liver DNA by agarose gel electrophoresis (1.2\%), in the presence of ethidium bromide. Fixation time $=3$ months. References $=1 \mathrm{~Kb}$ marker (lane 1), Pontoporia blainvillei (2-14), Stenella coeruleoalba (15) and Ziphius cavirostris (16). 


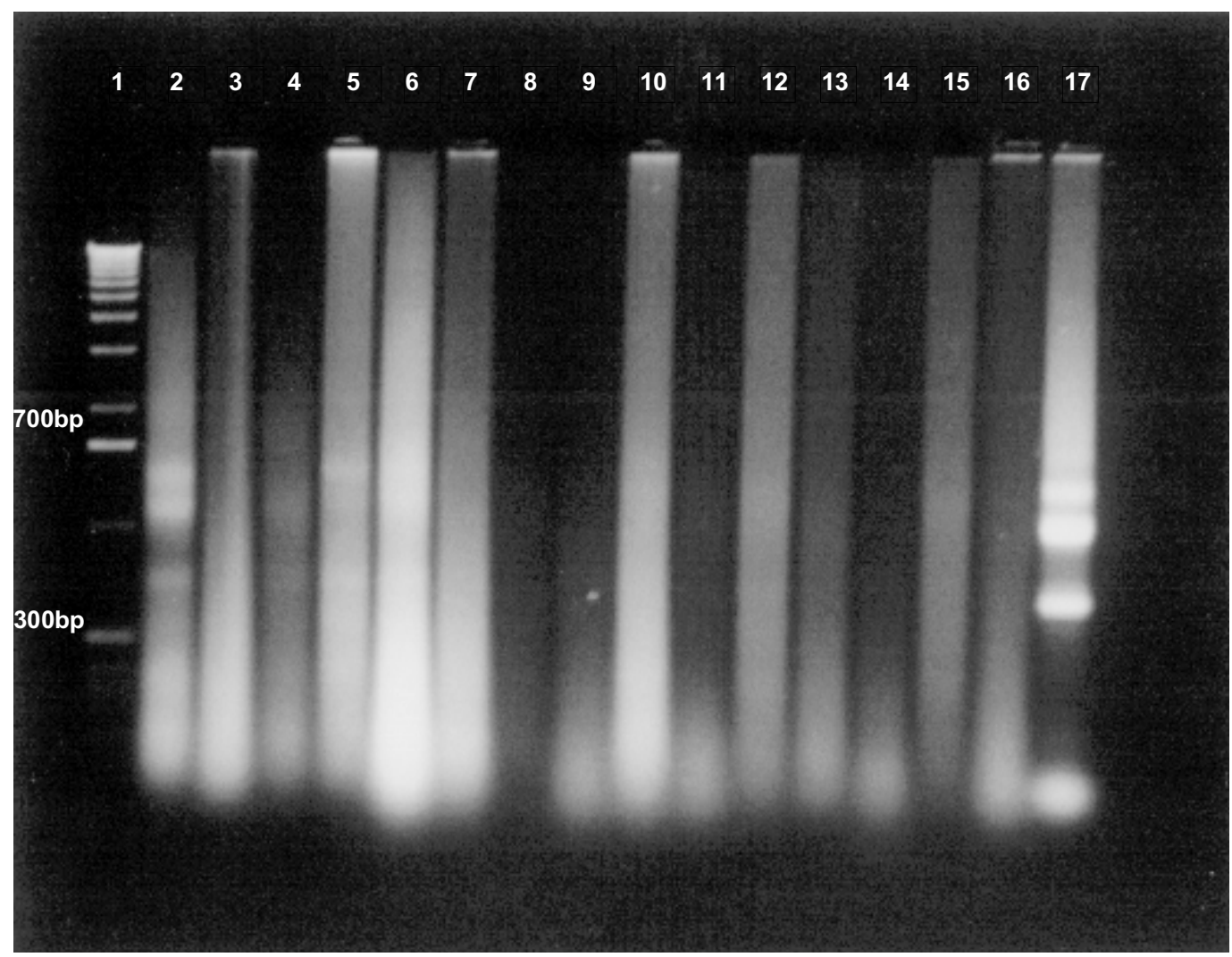

Figure 2. Separation of muscle and liver DNA by agarose gel electrophoresis (1.2\%), in the presence of ethidium bromide Fixation time $=3$ months. References $=1 \mathrm{~Kb}$ marker (lane 1), Arctocephalus australis (2), Arctocephalus tropicalis (3), Arctocephalus gazella (4), Otaria flavescens (5), Mirounga leonina (6), Pontoporia blainvillei (7), Delphinus delphis (8), Tursiops truncatus (9), Stenella coeruleoalba (10), Orcinus orca (11), Phocoena spinipinnis (12), Ziphius cavirostris (13), Kogia breviceps (14), Physeter catodon (15), Eubalaena australis (16) and Oncorhynchus mykiss (17) (fresh tissue).

tagging (Palsboll et al., 1997) and determination of genetic distances among populations (Allen et al., 1995; Andersen et al., 1997; Valsecchi et al., 1997). Moreover, the same primers have been shown to work in several species, as in the case of both cetaceans (Schlotterer et al., 1991; Valsecchi and Amos, 1996) and pinnipeds (Coltman et al., 1996; Amos, pers. comm). Amplification failure is frequently reported with degraded DNA, mainly of fragments longer than 300-500 bp (Karlsen et al., 1994; Dizon et al., 1995; Vachot and Monerot, 1996; Kimura et al., 1997). Such problems have been suggested to be correlated to changes in base structure (Karlsen et al., 1994) although Vachot and Monerot (1996) reported no sequence variation after formalin exposure. Future studies should focus on the amplification and sequencing of degraded DNA obtained from formalin fixed tissues, in order to evaluate the possibility of obtaining proper genotypes and the potential utilisation of such material in more complex analyses.

It is of special interest to have a method that allows the utilisation of samples not originally preserved for genetic studies. Museum or laboratory collections usually have fixed tissues of some rarely available, severely declining or nearly extinct species, as the case of beaked whales, monk seals or river dolphins. With the restrictions discussed above, the DNA extraction from formalin fixed tissues opens great possibilities for future studies. Genetic studies on Pontoporia blainvillei are recent and scarce (e.g. Secchi et al., 1998), whereas formalinbased collections exceed those DMSO-based or cryopreserved. Hopefully molecular data derived from archival specimens will complement other studies on the franciscana.

\section{Acknowledgements}

Several colleagues and institutions made this study possible. Birgitta Grahn and Liselotte Westerlund (Umeå University, Sweden) gave invaluable lab assistance. Sample collection was made in collaboration with Sergio Morón and Laura Rivero (Fundación Mundo Marino, CONICET and Universidad Nacional de Mar del Plata, Argentina). This study was funded by the Swedish Environmental Protection Board through a grant to Per-Erik Olsson, Fundación Antorchas (Project A13396/1-000064), Academia de Ciencias de América Latina, Universidad Nacional de Mar del Plata (Projects 15E005/15E102 and Travel Grant OCS 005/96) and Agencia Nacional de Promoción Científica y Tecnológica (PICT97 07-00000-01651 and PICT99 0107111) grants to Ricardo Bastida and Diego Rodríguez. Dr. William Amos (Cambridge University, United Kingdom) made helpful suggestions to the original manuscript. Comments 
and criticism from the two reviewers, Drs. Elena Valsecchi and John Wang, resulted in a much improved final version.

\section{References}

Allen, P.J., Amos, W., Pomeroy, P.P. and Twiss, S.D. (1995) Microsatellite variation in grey seals (Halichoerus grypus) shows evidence of genetic differentiation between two British breeding colonies. Molecular Ecology 4: 653-662.

Amos, W. and Hoelzel, A.R. (1991) Long term preservation of whale skin for DNA analysis. Pages 99-104 in Hoelzel, A.R. (Ed.) Genetic Ecology of Whales and Dolphins. International Whaling Commission Special Issue 13, Cambridge.

Amos, W., Twiss, S., Pomeroy, P.P. and Anderson, S.S. (1993) Male mating success and paternity in the grey seal, Halychoerus grypus: a study using DNA fingerprinting. Proceedings of the Royal Society of London Series B 252: 199-207.

Andersen, L.W., Holm, L.E., Siegismund, H.R., Clausen, B., Kinze, C.C. and Loeschcke, V. (1997) A combined DNA-microsatellite and isozyme analysis of the population structure of the harbour porpoise in Danish and West Greenland. Heredity 78: 270-276.

Bilton, D.T. and Jaarola, M. (1993) Isolation and purification of vertebrate DNAs. Pages 25-37 in Clapp, J.P. and Kimmel, A.R. (Eds) Species Diagnostics Protocols: PCR and other Nucleic Acid Methods. Methods in Molecular Biology Volume 50, Humana Press Inc., Totowa, USA.

Bruford, M.W. and Wayne, R.K. (1993) Microsatellites and their application in population genetic studies. Current Opinions in Genetics and Development 3: 939-943.

Cano, R.J. and Poinar, H.N. (1993) Rapid isolation of DNA from fossil and museum specimens suitable for PCR. Biotechniques 15: $432-436$

Clapham, P.J. and Palsboll, P. (1997) Molecular analysis of paternity shows promiscuous mating in female humpback whales (Megaptera novaeangliae Borowsky). Proceedings of the Royal Society of London Series B 264: 95-98.

Coltman, D.W., Bowen, D.W. and Wright, J.M. (1996) PCR primers for harbour seal (Phoca vitulina concolour) microsatellites amplify polymorphic loci in other Pinniped species. Molecular Ecology 5: 161-163.

Criscuolo, G. (1992) Extraction and amplification of DNA from wet museum collections. Ancient DNA Newsletter 1: 12-13.

Dessauer, H.C. and Hafner, M.S. (1984) Collections of frozen tissues: Value, management, field and laboratory procedures, and directory of existing collections. Report of the Association of Systematics Collections, Lawrence.

Dierauf, L.A. (1994) Pinniped forensic, necropsy and tissue collection guide. NOAA Technical Memorandum NMFS-OPR-94-3.

Dizon, A., Lux, C., LeDuc, R., Urban Ramirez, J., Henshaw, M. and Brownell Jr., R.L. (1995) An interim phylogenetic analysis of sei and Bryde's whales mitochondrial DNA control region sequences. Paper SC/47/NP23 presented at the $47^{\text {th }}$ Scientific Committee Meeting of the International Whaling Commission, Dublin, May, 1995. 10pp.

Goebel, A.M. and Simmons, J.E. (1993) Preserving DNA in liquidpreserved museum specimens. Pages 34-52 in Snyder, A.M. (Ed.) The 1992 American Society of Ichtiologists and Herpetologists Workshop on Collection Care and Management Issues. Publication of the Division of Herpetology, Kansas.

Golstein, D.M. and Schlotterer, J.E. (1993) Microsatellites: Evolution and applications. Oxford University Press, Oxford.

Greer, C.R., Peterson, S.L., Kiviat, N.B. and Manos, M.M. (1989) PCR amplification from paraffin embedded tissues: Effects of fixative and fixation times. American Journal of Clinical Pathology 95: 117-124.

Hagelberg, E., Bell, L.S., Allen, T., Bryde, A., Jones, S.J. and Clegg, J.B. (1991) Analysis of ancient bone DNA: techniques and applications. Proceedings of the Royal Society of London Series B 333: 399-407.

Hagelberg, E. and Clegg, B. (1991) Isolation and characterisation of DNA from archaeological bone. Proceedings of the Zoological Society of London Series B 244: 45-50.

Houde, P. and Braun, M.J. (1988) Museum collections as a source of DNA for studies of avian phylogeny. The Auk 105: 773-776.

Karlsen, E., Kalantari, M., Chitemerere, M., Johansson, B. and Hagmar, B. (1994) Modification of human and viral deoxyribonucleic acid by formaldehyde fixation. Laboratory Investigation 71: 604-611.

Kimura, T., Ogawa, T. and Pastene, L. (1997) Sample preparation and analysis of mitochondrial DNA from whale baleen plates. Marine Mammal Science 13: 495-498.

Kohn, M.H. and Wayne, R.K. (1997) Facts on faeces revisited. Trends in Ecology and Evolution 12: 223-227.

Paabo, S. (1989) Ancient DNA: extraction characterisation, molecular cloning and enzymatic amplification. Proceedings of the National Academy of Sciences of the U.S. 86: 1939-1943.

Paabo, S., Higuchi, R.G. and Wilson, A.T. (1989) Ancient DNA and the polymerase chain reaction. Journal of Biological Chemistry 264: 9709-9712.

Palsboll, P. (1999) Genetic tagging: contemporary molecular ecology. Biological Journal of the Linnean Society 68: 3-22.

Palsboll, P., Allen, J., Berube, M., Clapham, P.J., Feddersen, T.P., Hammond, P.S., Hudson, R.R., Jorgensen, H., Katona, S., Larsen, A.H., Lien, J., Mattila, D.K., Sigurjonson, J., Sears, R., Smith, T., Spencer, R., Stevik, P. and Oien, N. (1997) Genetic tagging of humpback whales. Nature 388: 767-796.

Queller, D.C., Strassmay, J.E. and Hughes, C.R. (1993) Microsatellites and kinship. Trends in Ecology and Evolution 8: 285-288.

Rassman, K., Schlotterer, C. and Tautz, D. (1991) Isolation of simple sequence loci for use in PCR-based DNA fingerprinting. Electrophoresis 12: 113-118.

Sambrook, J., Fritsch, E.F. and Maniatis, T. (1993) Molecular Cloning: a laboratory manual. 2nd Edition. Cold Spring Harbor Laboratory Press, Cold Spring Harbor.

Schlotterer, C., Amos, B. and Tautz, D. (1991) Conservation of polymorphic simple sequence loci in cetacean species. Nature 354: 63-65.

Secchi, E.N., Wang, J.Y., Murray, B., Rocha Ramos, C.C. and White, B.N. (1998) Population differentiation of the franciscana (Pontoporia blainvillei) from two geographic locations in Brazil as determined by mitochondrial DNA control region sequences. Canadian Journal of Zoology 76: 1622-1627.

Seutin, G., White, B.N. and Boag, P.T. (1991) Preservation of avian blood and tissue samples for DNA analyses. Canadian Journal of Zoology 69: 82-90.

Sherwin, W.B. (1991) Collecting mammalian tissue and data for genetic studies. Mammal Review 21: 21-30.

Stanta, G. and Schneider, C. (1991) RNA extracted from paraffin embedded human tissues is amenable to analysis by PCR amplification. Biotechniques 11: 306-308.

Tyrell, L., Elias, J. and Longley, J. (1995) Detection of specific mRNA in routinely processed dermatopathology specimens. The American Journal of Dermatopathology 17: 476-483.

Vachot, A.M. and Monerot, M. (1996) Extraction, amplification and sequencing of DNA from formaldehyde-fixed specimens. Ancient Biomolecules 1: 3-16.

Valsecchi, E. and Amos, W. (1996) Microsatellite markers for the study of cetacean populations. Molecular Ecology 5: 151-156.

Valsecchi, E., Palsboll, P., Hale, P., Glockner-Ferrari, D., Ferrari, M., Clapham, P., Larsen, F., Mattila, D., Sears, R., Sigurjonsson, J., Brown, M., Corkeron, P. and Amos, B. (1997) Microsatellite genetic distances between oceanic populations of the humpback whale. Molecular Biology and Evolution 14: 355-362.

Wright, J.M. and Bentzen, P. (1994) Microsatellites: genetic markers for the future. Reviews in Fish Biology and Fisheries 4: 384-388. 


\section{APPENDIX I}

DNA extraction protocol for formalin preserved tissues (after Vachot and Monerot, 1996)

1. Wash four times 75-100mg of tissue with TE ( $\mathrm{pH}=8$; Sambrook et al., 1993).

2. Pulverise the sample in liquid nitrogen.

3. Add $460 \mu$ l of the Extraction Buffer $(\Phi)$ first and then $40 \mu$ l of Proteinase K (concentration $10 \mathrm{mg} / \mathrm{ml}$ ) to a final concentration of $0.8 \mathrm{mg} / \mathrm{ml}$.

4. Incubate 12 hours at $50^{\circ} \mathrm{C}$ with gentle shaking.

5. $\quad$ Add $41.2 \mu \mathrm{l}$ of Proteinase K.

6. Incubate another 12 hours at $50^{\circ} \mathrm{C}$ with gentle shaking.

7. Perform one Phenol/Chloroform (v/v) extraction using 550 $\mu \mathrm{l}$ of P/C. Mix gently.

8. Precipitate DNA by adding $1083 \mu \mathrm{l}$ of Ethanol and $153 \mu \mathrm{l}$ of $2 \mathrm{M} \mathrm{NaCl}$ (final concentration $0.2 \mathrm{M})$.

9. Precipitate overnight at $-20^{\circ} \mathrm{C}$.

10. Centrifugate at high speed for 15 minutes.

11. Rinse two times with $700 \mu$ of $70 \%$ Ethanol.

12. Air dry and resuspend pellet in $30 \mu \mathrm{TE}(\mathrm{pH}=8)$.

(Ф) Extraction Buffer:

$100 \mathrm{mM}$ tris- $\mathrm{HCl}(\mathrm{pH}=8)$

$10 \mathrm{mM}$ EDTA

$100 \mathrm{mM} \mathrm{NaCl}$

$2 \%$ SDS

$50 \mathrm{mM}$ Dithiothreitol 